\title{
Microbiological Quality and Variability of Natural Microbiota in Croatian Cheese Maturing in Lambskin Sacks
}

\author{
Jadranka Frece ${ }^{*}$, Marija Vrdoljak², Mija Filipčić ${ }^{1}$, Marko Jelić ${ }^{2}$ Iva Čanak ${ }^{1}$, \\ Željko Jakopović ${ }^{1}$,Jelka Pleadin ${ }^{3}$, Ivana Gobin ${ }^{4}$, Tibela Landeka Dragičević ${ }^{1}$ \\ and Ksenija Markov ${ }^{1}$ \\ ${ }^{1}$ Faculty of Food Technology and Biotechnology, Pierottijeva 6, HR-10000 Zagreb, Croatia \\ ${ }^{2}$ Polytechnic 'Marko Marulić', Petra Krešimira IV 30, HR-22300 Knin, Croatia \\ ${ }^{3}$ Croatian Veterinary Institute, Savska cesta 143, HR-10000 Zagreb, Croatia \\ ${ }^{4}$ Faculty of Medicine, Braće Branchetta 20, HR-51000 Rijeka, Croatia \\ Received: September 3, 2015 \\ Accepted: January 21, 2016
}

\begin{abstract}
Summary
As in the traditional production of cheese in lambskin sacks raw cow's or sheep's milk is mostly used, the purpose of this study is to see how the production affects the microbiological quality of the cheese. To do that, we tested 39 samples of raw cow's and sheep's milk, curd, ripened cheese (15, 30 and 45 days) and lambskin sacks for native microbial population. Two-thirds of the milk, curd and cheese samples had higher counts of staphylococci and enterobacteria than permitted by regulations. Not a single sample had Salmonella and Listeria monocytogenes, but we did find Escherichia coli in sheep's milk and cheese, and yeast and mould in both types of milk and cheese. Staphylococcus xylosus prevailed in lambskin sacks. Despite the high incidence of S. aureus, even in the final product, staphylococcal enterotoxin was detected in only two sheep's cheese samples. Among the lactic acid bacteria, Lactococcus lactis and Lactobacillus paracasei prevailed in cow's cheese, whereas Leuconostoc mesenteroides and Lactobacillus plantarum prevailed in sheep's cheese. In the lambskin sacks Leuconostoc mesenteroides and Lactobacillus plantarum were predominant. Our findings give an important insight into the fermentation and microbial ecology of the cheese in lambskin sacks.
\end{abstract}

Key words: cheese in lambskin sack, cow's milk, sheep's milk, microbiological quality, natural microbiota, pathogens

\section{Introduction}

Cheese in lambskin or sheepskin sacks (Sir iz mišine) is one of Croatian traditional farm produces dating back to the times when Illyrians and Thracians herded their sheep on the pastures of Dinara Mountain. They used sheepskin sacks to store and transport cheese from the mountain to the settlements in the valley (1). Similar cheese matured in animal skin sacks is also produced in Bosnia and Herzegovina, Montenegro, Turkey and Lebanon (2).

In contrast to industrial food products, traditional cheese is of particular interest to consumers who care about the nature, origin, and nutritional value of food (3). Much of their reputation they owe to the unique orga- 
noleptic properties and to indigenous microorganisms living in raw milk or natural starters (4). However, raw milk can also contain pathogenic bacteria that have been raising public health concern since the beginnings of dairy industry. The most common pathogenic bacteria in raw milk and milk products are Salmonella, Listeria monocytogenes, Staphylococcus aureus and Escherichia coli (5).

It is therefore necessary to characterise traditional cheese not only to protect its diversity but also to control the quality (6). Yet artisanal cheese matured in animal skin has been poorly characterised, except for some Turkish and Lebanese varieties (7-9).

It is known that the microbiological quality of dairy products can be improved by adding a starter culture such as lactic acid bacteria (LAB) that will prevent the growth of pathogenic microorganisms $(5,10-13)$. The best way to preserve specific qualities of traditional cheese is to use an indigenous starter culture. Yet, lambskin cheese is traditionally produced without adding one.

The aim of our study is to characterise this unique product for the first time and to determine the natural microbiota in traditional dairy products.

\section{Materials and Methods}

\section{Cheese production and sampling}

Given that there are about ten small producers of cheese in lambskin sacks of similar size in the area of Knin (Croatia), we picked at random three that produce cow's milk cheese (sampling locations I-III) and three that produce sheep's milk cheese (sampling locations IV-VI). All samplings took place from May to July 2013.

For each cheese sample about $60 \mathrm{~L}$ of milk were taken. Evening milk was cooled to $7-12^{\circ} \mathrm{C}$, depending on the farm, and mixed with fresh morning milk. All producers used the same commercial microbial rennet in the ratio of 1:10 000 (Milaco, Split, Croatia) at temperatures between 32 and $37^{\circ} \mathrm{C}$. After 30 to $50 \mathrm{~min}$, the curd was scooped into small irregular pieces or cut with a knife into $3 \mathrm{~cm} \times 3$ $\mathrm{cm} \times 3 \mathrm{~cm}$ cubes. It was then heated to 34 to $40{ }^{\circ} \mathrm{C}$ (the temperature varied by farm) and stirred by hand or a scoop for 20 to $30 \mathrm{~min}$, at which point the first whey was drained. The curd was then shaped by hand, scooped and left to drain overnight through a cloth under its own weight. After the rest of the whey was removed, the curd was cut into $10 \mathrm{~cm} \times 9 \mathrm{~cm} \times 5 \mathrm{~cm}$ pieces, salted with coarse sea salt and stuffed in lambskin sacks. Cheese matured in lambskins for 45 days at 16 to $18{ }^{\circ} \mathrm{C}$ and relative humidity from 65 to $80 \%$. The average mass of mature cheese was about $20 \mathrm{~kg}$.

The lambskin sacks in which the cheese matures are made by gently skinning a freshly slaughtered lamb and carefully scraping off the remaining flesh and fat to avoid tearing. The skin is then cleaned with water, sun-dried, and finally smoked. Before it is filled with curd, the skin is submerged in whey or hot water. All openings are then sealed tight with a rope, except the neck, which is left open for stuffing with curd.

For microbiological analysis one of the following samples was taken per farm: raw cow's and sheep's milk, curd and cheese matured for 45 days. Milk samples were taken on the same day after the morning milking and curd samples immediately after coagulation.

In addition, two more samples of cheese were taken from each farm on days 15 and 30 of ripening for determination of LAB and staphylococci. Also, three empty lambskin sacks were taken for sampling.

Cheese samples (about $100 \mathrm{~g}$ per sample) were taken with a sterile knife through the neck opening of the sack. Curd (day 0) and cheese (days 15, 30 and 45 of ripening) were taken from each batch and transported to the laboratory on the same day in a mobile cooler at $4{ }^{\circ} \mathrm{C}$. About $0.5 \mathrm{~cm}$ of the sample surface were scraped off and the rest was stored at $-80^{\circ} \mathrm{C}$ until analysis. After each sampling, the skin sacks were tied up tight again and left in the ripening room at the family farm.

\section{Microbiological analyses}

Classical microbiological methods were used to isolate and identify pathogenic bacteria (after 0, 2 and 45 days of storage) and for the isolation of staphylococci and $\mathrm{LAB}$, the samples stored for 15 and 30 days were also used. At the same time lamb sacks were analysed for indigenous microbial populations.

A mass of $10 \mathrm{~g}$ of each sample was homogenised in $90 \mathrm{~mL}$ of sterile $0.5 \% \mathrm{NaCl}$ solution for $3 \mathrm{~min}$ using a Stomacher Lab Blender (Seward Limited, Worthing, UK) and serially diluted before plating (pour plate method for total aerobic mesophilic bacteria and spread plate method for other bacteria) on selective media. Total aerobic mesophilic bacteria were counted after incubation on nutrient agar (Merck, Darmstadt, Germany) at $37^{\circ} \mathrm{C}$ for $48 \mathrm{~h}, \mathrm{En}$ terobacteriaceae after incubation on Violet Red Bile Glucose (VRBG) agar (Biolife Italiana Srl, Milan, Italy) at $37^{\circ} \mathrm{C}$ for $48 \mathrm{~h}$, E. coli after incubation on RAPID'E. coli 2 agar (Biolife) at $37^{\circ} \mathrm{C}$ for $48 \mathrm{~h}$, Staphylococcus aureus after incubation on Baird-Parker (BP) agar (Biolife) at $37^{\circ} \mathrm{C}$ for $24 \mathrm{~h}$, mould and yeasts after incubation on potato dextrose agar (Biolife) at $25^{\circ} \mathrm{C}$ for $96 \mathrm{~h}$, and lactic acid bacteria after incubation on de Man, Rogosa and Sharpe (MRS) agar (Biolife) at $30^{\circ} \mathrm{C}$ for $48-72$ h. Salmonella sp. was grown in Rappaport-Vassiliadis (RV) Salmonella enrichment broth (Merck) according to ISO 6579:2002 method (14), followed by subculturing on xylose lysine deoxycholate (XLD) agar (Biolife) at $37{ }^{\circ} \mathrm{C}$ for $24-48 \mathrm{~h}$. Listeria monocytogenes was detected using a two-step selective enrichment procedure in Fraser broth according to ISO 11290-1:1996 method (15), followed by subculturing on PALCAM agar (Merck) at $37^{\circ} \mathrm{C}$ for $24 \mathrm{~h}$. The microbial growth was determined using traditional plate counting and the results are expressed as the logarithm of colony forming units per gram of cheese $(\log \mathrm{CFU} / \mathrm{g})$.

\section{Identification of microbial population}

To identify the indigenous microbial population, standard biochemical API ${ }^{\circledR} 50 \mathrm{CH}$ (for LAB) and $\mathrm{API}{ }^{\circledR}$ staph (for staphylococci) identification strips (bioMérieux, Vienna, Austria) were used. As many as 250 colonies were analysed in both cow's and sheep's milk, curd and cheese samples (after 0, 2, 15, 30 and 45 days of storage) as well as 80 colonies obtained from the lambskin sack samples. All colonies were collected after incubation on different agar media (MRS and BP). API identification of 
LAB and staphylococcal isolates was confirmed using a Microflex LT $^{\mathrm{TM}}$ matrix-assisted laser desorption-ionisation time-of-flight mass spectrometer (MALDI-TOF MS; Bruker Daltonik, Bremen, Germany) according to Babić et al. (11). For identification, the peaks from the generated mass spectra were compared with the reference spectra of the integrated database using the MALDI Biotyper Software package (Bruker Daltonik).

\section{Determination of enterotoxins}

To screen staphylococcal isolates from cow's and sheep's milk for potential ability to produce enterotoxins and to detect the presence of staphylococcal enterotoxins in dairy samples, the TECRA Staphylococcal Enterotoxins (SET) Visual Immunoassay (VIA) kit (TECRA Company, Kassel, Germany) was used. The kit can detect staphylococcal enterotoxins A (SEA), B (SEB), C (SEC), D (SED) and $\mathrm{E}$ (SEE).

\section{Statistical analysis}

All measurements/counts were carried out in triplicate. The results are expressed as mean value \pm standard deviation (S.D.).

\section{Results and Discussion}

Earlier studies on the composition, hygiene and quality of the cheese produced from raw milk in different countries have shown significant variations in hygiene standards, but all warn of health risks for the consumer $(8,12,16)$. In this sense, our study expands and supports the knowledge gathered so far with the findings on Croatian cheese in lambskin sacks, which is produced from raw cow's or sheep's milk on family farms in poorly controlled conditions, mostly during the summer. To establish the safety of cheese in lambskin sacks, our findings were compared with the Croatian cheese safety standards (17).

The microbiological analysis showed that two-thirds of the samples did not meet the safety criteria due to the high S. aureus and Enterobacteriaceae counts (Tables 1 and 2). However, colonies of Salmonella and L. monocytogenes were not found in any of the samples. Colonies of E. coli were not found in cow's milk but were present in sheep's milk samples (Table 2).

Milk can be contaminated by these microorganisms because of the poor hygiene, or animal udders and vessels that are not cleaned before milking. The high micro-

Table 1. Results of microbiological analyses and detection of staphylococcal enterotoxins in the samples of raw cow's milk, curd and ripened cheese in lambskin sacks

\begin{tabular}{|c|c|c|c|c|c|c|c|c|c|}
\hline$N($ microorganism) & San & pling locati & on I & Samp & ling locat & on II & Samp & ling locati & n III \\
\hline $\log \mathrm{CFU} / \mathrm{g}$ & Milk & Curd & Cheese & Milk & Curd & Cheese & Milk & Curd & Cheese \\
\hline Total aerobic bacteria & $4.2 \pm 1.0$ & $4.9 \pm 0.7$ & $4.4 \pm 1.1$ & $(6.0 \pm 1.5)^{* *}$ & $4.7 \pm 1.3$ & $4.0 \pm 1.7$ & $(5.1 \pm 1.4)^{* *}$ & $4.3 \pm 1.6$ & $4.9 \pm 1.9$ \\
\hline Enterobacteriaceae & $2.0 \pm 1.2$ & $1.8 \pm 0.7$ & $1.0 \pm 0.3$ & $1.8 \pm 1.0$ & $1.1 \pm 0.7$ & $0.8 \pm 0.2$ & $(2.2 \pm 0.8)^{*}$ & $1.6 \pm 0.8$ & $1.1 \pm 0.2$ \\
\hline E. coli & $<\mathrm{LD}$ & $<\mathrm{LD}$ & $<\mathrm{LD}$ & $<\mathrm{LD}$ & $<\mathrm{LD}$ & $<\mathrm{LD}$ & $<\mathrm{LD}$ & $<\mathrm{LD}$ & $<\mathrm{LD}$ \\
\hline S. aureus & $1.7 \pm 1.0$ & $(2.1 \pm 0.5)^{*}$ & $1.8 \pm 0.8$ & $(2.3 \pm 1.0)^{*}$ & $2.0 \pm 0.7$ & $1.9 \pm 0.8$ & $(2.2 \pm 0.7)^{*}$ & $1.9 \pm 0.7$ & $1.9 \pm 0.6$ \\
\hline L. monocytogenes & $<\mathrm{LD}$ & $<\mathrm{LD}$ & $<\mathrm{LD}$ & $<\mathrm{LD}$ & $<\mathrm{LD}$ & $<\mathrm{LD}$ & $<\mathrm{LD}$ & $<\mathrm{LD}$ & $<\mathrm{LD}$ \\
\hline Salmonella & $<\mathrm{LD}$ & $<\mathrm{LD}$ & $<\mathrm{LD}$ & $<\mathrm{LD}$ & $<\mathrm{LD}$ & $<\mathrm{LD}$ & $<\mathrm{LD}$ & $<\mathrm{LD}$ & $<\mathrm{LD}$ \\
\hline Moulds and yeasts & $<\mathrm{LD}$ & $<\mathrm{LD}$ & $1.1 \pm 0.8$ & $0.6 \pm 0.1$ & $<\mathrm{LD}$ & $<\mathrm{LD}$ & $1.6 \pm 0.9$ & $<\mathrm{LD}$ & $<\mathrm{LD}$ \\
\hline LAB & $4.2 \pm 0.8$ & $4.8 \pm 1.1$ & $5.4 \pm 1.0$ & $5.0 \pm 0.7$ & $5.0 \pm 0.9$ & $4.9 \pm 1.1$ & $4.6 \pm 1.2$ & $4.9 \pm 1.4$ & $5.4 \pm 1.4$ \\
\hline $\begin{array}{l}\text { Detection of staphylococcal } \\
\text { enterotoxins }\end{array}$ & negative & negative & negative & negative & negative & negative & negative & negative & negative \\
\hline
\end{tabular}

${ }^{*}$ not satisfactory criterion $(\leq 2 \log \mathrm{CFU} / \mathrm{g}),{ }^{* *}$ not satisfactory criterion $(\leq 5 \log \mathrm{CFU} / \mathrm{g}), \mathrm{LD}=$ limit of detection

Table 2. Results of microbiological analyses and detection of staphylococcal enterotoxins in the samples of raw sheep's milk, curd and ripened cheese in lambskin sacks

\begin{tabular}{|c|c|c|c|c|c|c|c|c|c|}
\hline \multirow{2}{*}{$\frac{N(\text { microorganism })}{\log \mathrm{CFU} / \mathrm{g}}$} & \multicolumn{3}{|c|}{ Sampling location IV } & \multicolumn{3}{|c|}{ Sampling location $\mathrm{V}$} & \multicolumn{3}{|c|}{ Sampling location VI } \\
\hline & Milk & Curd & Cheese & Milk & Curd & Cheese & Milk & Curd & Cheese \\
\hline Total aerobic bacteria & $(8.0 \pm 2.0)^{* *}$ & $(7.3 \pm 1.8)^{* *}$ & $(6.9 \pm 1.4)^{* *}$ & $(7.6 \pm 2.0)^{* *}$ & $(7.1 \pm 1.2)^{* *}$ & $(8.0 \pm 1.8)^{* *}$ & $(6.7 \pm 1.3)^{* *}$ & $(7.2 \pm 1.8)^{* *}$ & $(7.4 \pm 1.2)^{* *}$ \\
\hline Enterobacteriaceae & $(2.7 \pm 0.8)^{*}$ & $(2.9 \pm 0.7)^{*}$ & $(2.5 \pm 0.6)^{*}$ & $(2.2 \pm 0.9)^{*}$ & $(2.3 \pm 0.7)^{*}$ & $1.9 \pm 0.7$ & $(3.0 \pm 0.9)^{*}$ & $(2.3 \pm 0.9)^{*}$ & $2.0 \pm 0.8$ \\
\hline E. coli & $0.7 \pm 0.3$ & $<\mathrm{LD}$ & $<\mathrm{LD}$ & $<\mathrm{LD}$ & $<\mathrm{LD}$ & $<\mathrm{LD}$ & $1.1 \pm 0.4$ & $<\mathrm{LD}$ & $0.30 \pm 0.06$ \\
\hline S. aureus & $(3.3 \pm 1.1)^{*}$ & $(4.3 \pm 1.0)^{*}$ & $(5.5 \pm 1.6)^{*}$ & $(3.0 \pm 0.8)^{*}$ & $(5.0 \pm 1.2)^{*}$ & $(5.2 \pm 1.1)^{*}$ & $(3.8 \pm 0.8)^{*}$ & $(4.6 \pm 1.2)^{*}$ & $(6.3 \pm 1.1)^{*}$ \\
\hline L. monocytogenes & $<\mathrm{LD}$ & $<\mathrm{LD}$ & $<\mathrm{LD}$ & $<\mathrm{LD}$ & $<\mathrm{LD}$ & $<\mathrm{LD}$ & $<\mathrm{LD}$ & $<\mathrm{LD}$ & $<\mathrm{LD}$ \\
\hline Salmonella & $<\mathrm{LD}$ & $<\mathrm{LD}$ & $<\mathrm{LD}$ & $<\mathrm{LD}$ & $<\mathrm{LD}$ & $<\mathrm{LD}$ & $<\mathrm{LD}$ & $<\mathrm{LD}$ & $<\mathrm{LD}$ \\
\hline Moulds and yeasts & $0.5 \pm 0.1$ & $<\mathrm{LD}$ & $0.32 \pm 0.09$ & $<\mathrm{LD}$ & $<\mathrm{LD}$ & $<\mathrm{LD}$ & $<\mathrm{LD}$ & $<\mathrm{LD}$ & $1.0 \pm 0.3$ \\
\hline LAB & $3.5 \pm 1.5$ & $4.2 \pm 0.5$ & $4.7 \pm 0.5$ & $3.6 \pm 1.3$ & $4.2 \pm 1.1$ & $4.3 \pm 1.3$ & $3.6 \pm 1.2$ & $4.2 \pm 1.3$ & $4.5 \pm 1.4$ \\
\hline $\begin{array}{l}\text { Detection of staphylococcal } \\
\text { enterotoxins }\end{array}$ & negative & negative & positive & negative & negative & negative & negative & negative & positive \\
\hline
\end{tabular}

${ }^{*}$ not satisfactory criterion $(\leq 2 \log \mathrm{CFU} / \mathrm{g}),{ }^{* *}$ not satisfactory criterion $(\leq 5 \log \mathrm{CFU} / \mathrm{g}), \mathrm{LD}=$ limit of detection 
organism count can also be the consequence of poor handling and storage conditions. Overnight storage of milk at $7.2{ }^{\circ} \mathrm{C}$ allows microorganisms to grow much faster than at lower temperatures $(4,12)$.

The microbiological quality of lambskin sack samples was satisfactory, as no pathogens were found (results not shown).

As the limit of S. aureus of $2 \log$ CFU/g (17) was exceeded in two-thirds of milk, curd and cheese samples, all samples were tested for staphylococcal enterotoxins (SE), which resulted in detecting staphylococcal enterotoxin $\mathrm{C}$ (SEC) in two sheep's milk cheese samples (Table 2). These results indicate that this phase of sheep's milk cheese production is also at risk and that there is room for improvement in the production hygiene and/or selection of raw materials. The increase in S. aureus count in the curd during the first days of ripening (Table 2) suggests the possible risk at this stage of production and the need to take measures to improve the hygienic conditions. Various authors have confirmed rapid increase in S. aureus at the beginning of ripening $(18,19)$. The conditions under which cheese in lambskin sacks is processed are poor, which can be one of the major sources of contamination of the curd with $S$. aureus besides raw milk. SEC in the two sheep's milk cheese samples may also originate from animals suffering from mastitis. Our results are in agreement with literature sources which claim that only a small percentage of coagulase-positive staphylococci (CPS) is potentially enterotoxic and explain why SE are also rarely detected in the samples where CPS exceeds the values of $10^{5}$ CFU/g (14,20-22).
In contrast, only three cow's milk and curd samples and none of the cheese samples had $S$. aureus counts above the safety limit. One of the reasons for the better microbiological quality of cow's milk could be the higher lactic acid bacteria (LAB) counts that were enumerated in this milk compared to the sheep's milk (Tables 1 and 2), which confirms the findings by Durmaz (23), Kells and Gilmour (24), Lamprell et al. (25) and Schoder et al. (26). Many studies (5,10-13) have shown that lactic acid bacteria added to traditional fermented food as starter cultures can inhibit the growth of pathogenic and spoilage microorganisms, mainly due to the production of lactic acid, but they can also produce many other antimicrobial metabolites such as bacteriocins, organic acids, hydrogen peroxide, etc.

However, many traditionally fermented dairy products in Croatia and elsewhere are produced without the addition of starter cultures. To protect their specific qualities such as flavour and aroma, it is essential to understand the indigenous microbial interactions during fermentation and to isolate and characterise autochthonous starter cultures that can improve their safety $(10,13,27)$.

Using biochemical analysis nine indigenous bacterial species were identified in milk, curd and cheese samples: Lactobacillus plantarum, Lactococcus lactis, Leuconostoc mesenteroides, Lactobacillus paracasei, Lactobacillus curvatus, Lactobacillus brevis, Staphylococcus xylosus, S. aureus and S. epidermidis, with 99-99.9\% accuracy (Table 3). The prevalent strains of LAB were Lactococcus lactis and Lactobacillus paracasei in dairy samples from cow's milk and Leuconos-

Table 3. Results of biochemical identification of natural microbial populations of raw cow's and sheep's milk, curd and ripened cheese in lambskin sacks

\begin{tabular}{|c|c|c|c|c|c|c|c|}
\hline Sample & $\frac{t \text { (ripening) }}{\text { day }}$ & $N($ colony $)$ & $\begin{array}{l}\text { Identified } \\
\text { LAB }\end{array}$ & $N(\mathrm{LAB})$ & $N($ colony $)$ & $\begin{array}{c}\text { Identified } \\
\text { Staphylococcus sp. }\end{array}$ & $N($ Staphylococcus $)$ \\
\hline $\begin{array}{l}\text { Cow's } \\
\text { milk }\end{array}$ & 0 & 34 & $\begin{array}{c}\text { Lactococcus lactis ssp. lactis } \\
\text { Lactobacillus plantarum } \\
\text { Lactobacillus paracasei }\end{array}$ & $\begin{array}{r}18 \\
5 \\
11\end{array}$ & 19 & Staphylococcus epidermidis & 7 \\
\hline \multirow[t]{2}{*}{ Curd } & 2 & 38 & $\begin{array}{c}\text { Lactococcus lactis ssp. lactis } \\
\text { Lactobacillus paracasei }\end{array}$ & $\begin{array}{l}22 \\
16 \\
\end{array}$ & 16 & Staphylococcus epidermidis & 5 \\
\hline & 15 & 34 & $\begin{array}{c}\text { Lactococcus lactis ssp. lactis } \\
\text { Lactobacillus paracasei }\end{array}$ & $\begin{array}{l}21 \\
13\end{array}$ & n.d. & & \\
\hline \multirow[t]{2}{*}{ Cheese } & 30 & 33 & $\begin{array}{c}\text { Lactococcus lactis ssp. lactis } \\
\text { Lactobacillus paracasei }\end{array}$ & $\begin{array}{l}21 \\
12\end{array}$ & 18 & Staphylococcus xylosus & 16 \\
\hline & 45 & 38 & $\begin{array}{c}\text { Lactococcus lactis ssp. lactis } \\
\text { Lactobacillus paracasei }\end{array}$ & $\begin{array}{l}25 \\
13\end{array}$ & 20 & Staphylococcus xylosus & 17 \\
\hline $\begin{array}{l}\text { Sheep's } \\
\text { milk }\end{array}$ & 0 & 35 & $\begin{array}{l}\text { Leuconostoc mesenteroides } \\
\text { Lactococcus lactis ssp. lactis }\end{array}$ & $\begin{array}{l}23 \\
12 \\
\end{array}$ & 20 & $\begin{array}{c}\text { Staphylococcus aureus } \\
\text { Staphylococcus epidermidis }\end{array}$ & $\begin{array}{r}12 \\
5\end{array}$ \\
\hline Curd & 2 & 33 & $\begin{array}{l}\text { Lactococcus lactis ssp. lactis } \\
\text { Leuconostoc mesenteroides }\end{array}$ & $\begin{array}{l}20 \\
13\end{array}$ & 17 & Staphylococcus aureus & 11 \\
\hline \multirow{3}{*}{ Cheese } & 15 & 35 & $\begin{array}{c}\text { Lactobacillus curvatus ssp. curvatus } \\
\text { Leuconostoc mesenteroides } \\
\text { Lactobacillus plantarum }\end{array}$ & $\begin{array}{r}6 \\
11 \\
18\end{array}$ & n.d. & & \\
\hline & 30 & 36 & $\begin{array}{l}\text { Leuconostoc mesenteroides } \\
\text { Lactobacillus plantarum }\end{array}$ & $\begin{array}{l}14 \\
22\end{array}$ & 17 & Staphylococcus $x y$ losus & 10 \\
\hline & 45 & 39 & $\begin{array}{l}\text { Lactobacillus brevis } \\
\text { Leuconostoc mesenteroides } \\
\text { Lactobacillus plantarum }\end{array}$ & $\begin{array}{r}2 \\
10 \\
27\end{array}$ & 18 & Staphylococcus xylosus & 11 \\
\hline
\end{tabular}


toc mesenteroides and Lactobacillus plantarum in those from sheep's milk. In lambskin sacks the prevalent lactobacilli were Leuconostoc mesenteroides and Lactobacillus plantarum (Table 4). These findings give an important insight into the fermentation and microbial ecology of cheese in lambskin sacks and suggest that the isolated LAB and staphylococcal strains (S. xylosus) may play an important role in defining its recognisable and desired aroma. The exact role of these bacteria in the taste formation remains to be elucidated.

Table 4. Results of biochemical identification of microbial population in the lambskin sacks

\begin{tabular}{cccc}
\hline $\begin{array}{c}\text { Lambskin } \\
\text { sack } \\
\text { sample }\end{array}$ & $N$ (colony) & Microorganism & $\begin{array}{c}N(\text { micro- } \\
\text { organism) }\end{array}$ \\
\hline Bottom & 16 & Lactobacillus plantarum & 9 \\
& 11 & $\begin{array}{c}\text { Leuconostoc mesenteroides } \\
\text { Staphylococcus xylosus }\end{array}$ & 7 \\
\hline Centre & 15 & Leuconostoc mesenteroides & 8 \\
& 10 & Lactobacillus plantarum & 7 \\
& 17 & Staphylococcus xylosus & 6 \\
\hline Top & 11 & Lactobacillus curvatus & 4 \\
& & Lactobacillus plantarum & 6 \\
& & Seuconostoc mesenteroides & 7 \\
& & Staphylococcus xylosus & 6 \\
\hline
\end{tabular}

\section{Conclusion}

Our study was the first to isolate and identify the indigenous microbial population in Croatian traditional cheese in lambskin sacks obtained from either raw cow's or sheep's milk. It has shown that sheep's milk, curd and cheese in lambskin sacks contain bacteria that are generally considered indicators of poor hygiene, but indigenous LAB were also identified that may serve as starter cultures and improve cheese quality and safety. We consider these findings as a first step in future research to identify indigenous LAB that can be used as starter cultures (through their technological and functional characterisation) and which hygiene improvements to use, without affecting the unique organoleptic properties of cheese in lambskin sacks. This will set the grounds for obtaining the quality scheme Protected Designation of Origin, which would make this product desirable for potential markets in Croatia and all over the world.

\section{Acknowledgements}

We would like to thank all the producers of cheese in lambskin sacks for participating in this study and $\mathrm{Mr}$ Dado Čakalo for his help in the English editing of the manuscript.

\section{References}

1. Tudor Kalit M, Kalit S, Delaš I, Kelava N, Karolyi D, Kaić D, et al. Changes in the composition and sensory properties of Croatian cheese in a lamb skin sack (Sir iz mišine) during ripening. Int J Dairy Technol. 2014;67:255-64.

http://dx.doi.org/10.1111/1471-0307.12117
2. Tudor Kalit M, Marković K, Kalit S, Vahčić N, Havranek J. Application of electronic nose and electronic tongue in the dairy industry. Mljekarstvo. 2014;64:228-44.

http://dx.doi.org/10.15567/mljekarstvo.2014.0402

3. Shahab Lavasani AR, Ehsani MR, Mirdamadi S, Mousavi MAEZ. Changes in physicochemical and organoleptic properties of traditional Iranian cheese Lighvan during ripening. Int J Dairy Technol. 2012;65:64-70. http://dx.doi.org/10.1111/j.1471-0307.2011.00724.x

4. Serhan M, Mattar J. Characterization of four Lebanese artisanal goat milk cheeses: Darfiyeh, Aricheh, Shankleesh and Serdale by physico-chemical, microbiological and sensory analyses. J Food Agric Environ. 2013;11:97-101.

5. Markov K, Perši N, Pleadin J, Čvek D, Radošević V, Delaš F, et al. Characterization of natural microflora and chemical parameters in fresh domestic cheese. Veterinarska stanica. 2011;42:211-8 (in Croatian).

6. Ercan D, Korel F, Karagül Yüceer Y, Kınık Ö. Physicochemical, textural, volatile, and sensory profiles of traditional Sepet cheese. J Dairy Sci. 2011;94:4300-12. http://dx.doi.org/10.3168/jds.2010-3941

7. Ceylan ZG, Çağlar A, Çakmakçi S. Some physicochemical, microbiological and sensory properties of tulum cheese produced from ewe's milk via a modified method. Int J Dairy Technol. 2007;60:191-6. http://dx.doi.org/10.1111/j.1471-0307.2007.00326.x

8. Serhan M, Linder M, Hosri C, Fanni J. Changes in proteolysis and volatile fraction during ripening of Darfiyeh, a Lebanese artisanal raw goat's milk cheese. Small Ruminant Res. 2010;90:75-82.

http://dx.doi.org/10.1016/j.smallrumres.2010.01.008

9. Yilmaz G, Ayar A, Akin N. The effect of microbial lipase on the lipolysis during the ripening of Tulum cheese. J Food Eng. 2005;69:269-74.

http://dx.doi.org/10.1016/j.jfoodeng.2004.08.017

10. Ayad EHE. Starter culture development for improving safety and quality of Domiati cheese. Food Microbiol. 2009;26: 533-41. http://dx.doi.org/10.1016/j.fm.2009.03.007

11. Babić I, Markov K, Kovačević D, Trontel A, Slavica A, Đugum J, et al. Identification and characterization of potential autochthonous starter cultures from a Croatian 'brand' product 'Slavonski kulen'. Meat Sci. 2011;88:517-24. http://dx.doi.org/10.1016/j.meatsci.2011.02.003

12. Hayaloglu AA, Fox PF, Guven M, Cakmakci S. Cheeses of Turkey: 1. Varieties ripened in goat-skin bags. Lait. 2007;87: 79-95. http://dx.doi.org/10.1051/lait:2007006

13. Hayaloglu AA, Guven M, Fox PF. Microbiological, biochemical and technological properties of Turkish white cheese 'Beyaz Peynir'. Int Dairy J. 2002;12:635-48. http://dx.doi.org/10.1016/S0958-6946(02)00055-9

14. ISO 6579:2002. Microbiology of food and animal feeding stuffs - Horizontal method for the detection of Salmonella spp. Geneva, Switzerland: International Organization for Standardization (ISO); 2002.

15. ISO 11290-1:1996. Microbiology of food and animal feeding stuffs - Horizontal method for the detection and enumeration of Listeria monocytogenes - Part 1: Detection method. Geneva, Switzerland: International Organization for Standardization (ISO); 1996.

16. Rysha A, Markov K, Frece J, Čvek D, Delaš F. A survey of the microbiological quality of Sharri, a hard mountain cheese from Kosovo. Int J Dairy Technol. 2013;66:277-82. http://dx.doi.org/10.1111/1471-0307.12080 
17. Ordinance on Microbiological Criteria for Food No. 89. Zagreb, Croatia: Official Gazette of the Republic of Croatia; 2010 (in Croatian).

18. Gómez-Lucía E, Goyache J, Orden JA, Domenech A, Javier Hernandez F, Ruiz-Santa Quiteria JA, et al. Growth of Staphylococcus aureus and synthesis of enterotoxin during ripening of experimental Manchego-type cheese. J Dairy Sci. 1992; 75:19-26. http://dx.doi.org/10.3168/jds.S0022-0302(92)77733-9

19. Meyrand A, Boutrand-Loei S, Ray-Gueniot S, Mazuy C, Gaspard CE, Jaubert G, et al. Growth and enterotoxin production of Staphylococcus aureus during the manufacture and ripening of Camembert-type cheeses from raw goat's milk. J Appl Microbiol. 1998;85:537-44. http://dx.doi.org/10.1046/j.1365-2672.1998.853531.x

20. Meyer-Broseta M, Diot A, Bastian S, Rivière J, Cerf O. Estimation of low bacterial concentration: Listeria monocytogenes in raw milk. Int J Food Microbiol. 2003;80:1-15. http://dx.doi.org/10.1016/S0168-1605(02)00117-4

21. Markov K, Frece J, Čvek D, Delaš F. Listeria monocytogenes and other contaminants in fresh cheese and cream from $\mathrm{Za}$ greb city area domestic production. Mljekarstvo. 2009;59: 225-31 (in Croatian).

22. Sesques M, Ballot N. Growth of Staphylococcus aureus during manufacturing of raw milk cheeses with controlled designation of origin from Massif Central. Proceedings of Con- grilait - 26th IDF World Dairy Congress; 2002 September 24-27; Paris, France; 2002 (in French).

23. Durmaz H. Fate of Listeria monocytogenes in Carra cheese during manufacture and ripening. J Food Safety. 2009;29:25360. http://dx.doi.org/10.1111/j.1745-4565.2009.00154.x

24. Kells J, Gilmour A. Incidence of Listeria monocytogenes in two milk processing environments, and assessment of Listeria monocytogenes blood agar for isolation. Int J Food Microbiol. 2004;91:167-74. http://dx.doi.org/10.1016/S0168-1605(03)00378-7

25. Lamprell H, Villard L, Chamba JF, Beuvier E, Borges E, Maurin $\mathrm{F}$, et al. Identification and biotyping of coagulase positive staphylococci (CPS) in ripened French raw milk cheeses and their in vitro ability to produce enterotoxins. Revue Méd Vét. 2004;155:92-6.

26. Schoder D, Zangana A, Paulsen P, Winter P, Baumgartner W, Wagner M. Ovine Listeria monocytogenes mastitis and human exposure via fresh cheese from raw milk - the impact of farm management, milking and cheese manufacturing practices. Milchwissenschaft. 2008;63:258-62.

27. Cocolin L, Nucera D, Alessandria V, Rantsiou K, Dolci P, Grassi MA, et al. Microbial ecology of Gorgonzola rinds and occurrence of different biotypes of Listeria monocytogenes. Int J Food Microbiol. 2009;133:200-5.

http://dx.doi.org/10.1016/j.ijfoodmicro.2009.05.003 